\title{
Seasonal and Spatial Variability of Primary Production in the Mozambique Channel
}

\author{
Avelino Ângelo Adolfo Langa ${ }^{1,2}$ \\ ${ }^{1}$ Institute of Oceanography, Federal University of Rio Grande - IO, FURG, Rio Grande, Brazil \\ ${ }^{2}$ School of Marine and Coastal Sciences, Eduardo Mondlane University - ESCMC-UEM, Quelimane, Mozambique
}

\section{Email address:}

avelinolanga@yahoo.com.br

\section{To cite this article:}

Avelino Ângelo Adolfo Langa. Seasonal and Spatial Variability of Primary Production in the Mozambique Channel. Journal of Water Resources and Ocean Science. Vol. 10, No. 3, 2021, pp. 61-67. doi: 10.11648/j.wros.20211003.14

Received: May 12, 2021; Accepted: June 16, 2021; Published: June 26, 2021

\begin{abstract}
The surface circulation in the Mozambique Channel changes from the northern part, where the system is under dominance of the monsoons, to the central and southern parts, where mesoscale eddies are more frequent. Despite these differences in the physics between the three regions, satellite-based primary production shows that the whole region is characterized by similar seasonal variability of primary production, in which winter is the most productive season. A coupled physical-biogeochemical model configuration applied for the Mozambique Channel is used to investigate how wind stress and heat fluxes modulate seasonally and spatially the distribution of new and primary production in the region. Higher new production integrated over the euphotic layer depth in winter accounts for about $50 \%$ of the total primary production in the Mozambique Channel, indicating the seasonality of primary production is driven by new nutrients upwelled from bellow the euphotic zone. During the other seasons of the year the depth-integrated primary production is low, which is the period when the system depends on remineralization of the organic matter to sustain phytoplankton growth at the subsurface. Stronger wind stress is the dominant surface forcing in the northern part of the Mozambique Channel, which is responsible for vertical advection and entrainment of nitrate from below the euphotic zone that sustain the primary production during winter, while intense negative net heat flux is the dominant forcing in the central/southern parts. However, it is important to note that mesoscale eddies also enhance primary productivity in the region with a focus on the winter period.
\end{abstract}

Keywords: Wind Stress, Heat Fluxes, New Production, Primary Production, Mozambique Channel

\section{Introduction}

The Mozambique Channel is located between the countries of Mozambique in mainland and the Island of Madagascar. The main water masses that characterize the upper layers are the Tropical Surface Waters (TSW, $<25 \mathrm{~kg} \mathrm{~m}^{-3}$ ) and Subtropical Surface Water (STSW, $25.8 \mathrm{~kg} \mathrm{~m}^{-3}$ ) [1]. To the north, warm and less saline surface waters of the TSW are brought into the area by the South Equatorial Current [2]. The transition zone between TSW and STSW occurs in the central part of the channel at around $22^{\circ} \mathrm{S}$, where vertical and horizontal mixing modifies the two water masses. STSW enters the Mozambique Channel from the southern part, where salinity increases due to larger evaporation, which exceeds precipitation, turning into a subsurface salinity maximum when these waters subduct below the low-salinity water [3].

The surface circulations in the region are dominated by mesoscale eddies moving from north to south, instead of a continuous current located near the coast of Mozambique [4-6]. With a diameter of about $300 \mathrm{~km}$ and moving at 3 to 6 $\mathrm{km} \mathrm{day}^{-1}$ [7], eddies in the region interact with the coastal waters and than advect biogeochemical properties into the mid-channel [8]. Due to nutrient-rich deeper water upwelled by mesoscale eddies, these features are known to significantly increase the biological activity in the open sea [9-11].

Recently, the Mozambique Channel has received considerable attention in terms of studies on biophysical interactions, however, the effects of physical forcing on the primary production is still to be investigated. In situ measurements indicate that primary production in the Mozambique Channel varies from 0.11 to $0.50 \mathrm{~g} \mathrm{C} \mathrm{m}^{-2}$ day $^{-1}$ in the open ocean to $>1.0 \mathrm{~g} \mathrm{C} \mathrm{m}^{-2}$ day $^{-1}$ in the shelf [12]. Satellite estimations of surface biological production in the whole region indicate a seasonal variation of the chlorophyll 
concentrations in the Mozambique Channel, characterized by higher rate in winter than in the other seasons [13]. The main mechanisms proposed for the primary production variability in the area are the wind field [14] and mesoscale eddies [15]. Apart from wind stress, vertical mixing associated with heat loss during winter leads to a deeper mixed layer depth, thus indicating its important role on the seasonal variability of the surface chlorophyll concentrations in the northern Mozambique Channel [16]. It is unknown, however, how the mixing processes due to wind stress and heat fluxes affect spatially and seasonally the distribution of depth integrated primary production in the highly mesoscale eddies activity region of the Mozambique Channel.

Thus, the present study investigates the driving mechanisms of the seasonal and spatial distribution of new production and primary production in the Mozambique Channel. The major difference in physical forcing between the northern and the other regions of the Mozambique Channel is the presence of intense mesoscale eddies in the central and southern parts while in north the circulation is strongly influenced by the monsoons.

\section{Methodology}

\section{Model configuration}

The present study used outputs from Regional Ocean Modeling System (ROMS; [17]) coupled to Pelagic Interaction Scheme for Carbon and Ecosystem Studies (PISCES; [18, 19]) configured for the Mozambique Channel [16]. ROMS is a free-surface, terrain-following vertical coordinates ocean model, which solves primitive equations, based on Boussinesq and Hydrostatic approximations. PISCES were used to simulate the biogeochemical processes in the Mozambique Channel. 24 (twenty four) compartments compose this biogeochemical model, which includes two phytoplankton compartments (diatoms and nano-phytoplankton), and two zooplankton size classes (meso-zooplankton and micro-zooplankton). A higher hydrodynamic configuration for Mozambique Channel is of horizontal resolution of $1 / 12^{\circ}$, and has 40 sigma-coordinate vertical levels, covering the geographic area limited by $5.3^{\circ}$ to $32.9^{\circ} \mathrm{S}$ of latitude and from $34^{\circ}$ to $68.1^{\circ} \mathrm{E}$ of longitude. The bottom topography used for the configuration is derived from the 30 arc sec GEBCO (GEneral Bathymetric Chart of the Oceans: http://www.gebco.net) dataset and has been smoothed in order to avoid possible error in the horizontal pressure gradient. The ROMS-PISCES configurations and descriptions for the Mozambique Channel and the proper evaluations of the model outputs are described in details in the previous study [16].

The study also used additional data derived from Vertical Generalized Primary Production Model (VGPM) for depth-integrated primary production [20]. VGPM is widely used as an estimation of global primary production. It uses variables such as temperature, surface chlorophyll and photo-synthetically active radiation, all obtained from satellite estimations. VGPM provides primary production integrated over the euphotic layer depth and the data is available at http://www.science.oregonstate.edu/ocean.productivity.

\section{Results and Discussion}

\subsection{Surface Wind Stress and Net Heat Flux Variability}

The present study highlights the influence of wind stress and neat heat flux in the seasonal and spatial distribution of depth-integrated primary production in the Mozambique Channel. Before the analysis of primary production variability in the next subsection, a brief description of wind stress and heat fluxes is presented in the following paragraphs.

The wind regime in the Mozambique Channel is seasonal, marked by high values of wind stress in winter and low winds in the summer period (Figure 1). The northern region of the Mozambique Channel differs from the central and southern parts due to the fact that the north is under the influence of monsoons [2].
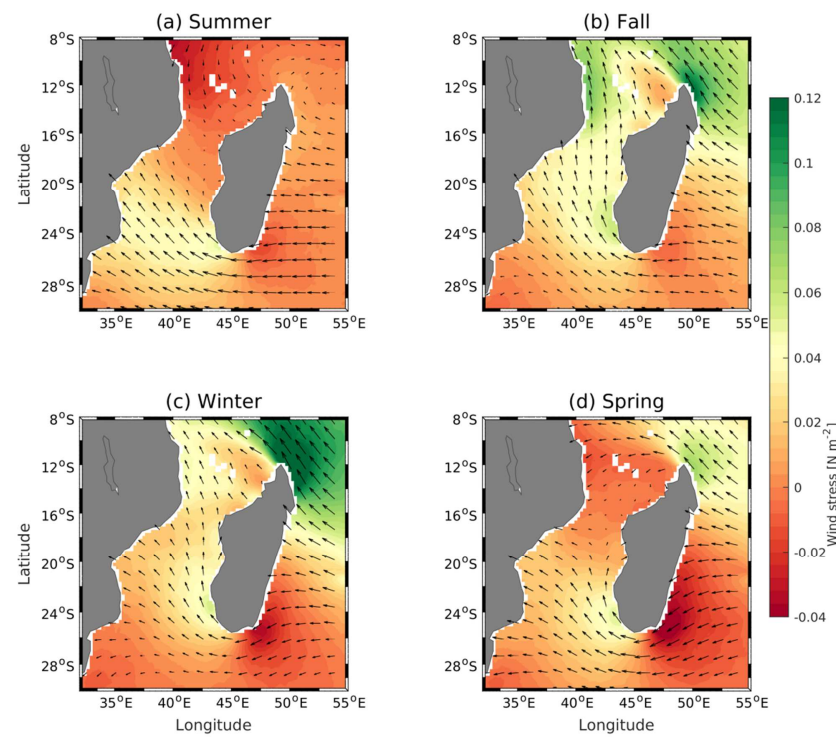

Figure 1. The maps show the temporal and spatial variability of wind stress (color) in the Mozambique Channel. The arrows indicate the wind direction. The climatological data is derived from QSCAT dataset.

Monsoons in the Northern Mozambique Channel are characterized by the seasonal change in the direction of the wind, blowing from the north to northeast during the summer (Figure 1-a) and from the south to the southeast in fall and winter (Figure 1- $\mathrm{b} \& \mathrm{c}$ ). The monsoon system that influences the north of the Mozambique Channel up to $18^{\circ} \mathrm{S}$ latitude is an extension of the monsoon winds of the northern Indian Ocean.

The central and southern regions of the Mozambique Channel are influenced by winds from the south/southeast, prevailing in this direction throughout the year. Values of wind stress in both central and southern regions are less than $0.1 \mathrm{~N}$ $\mathrm{m}^{-2}$ and with slightly seasonal variability.

Similar to the wind stress, net heat flux in the Mozambique Channel is also seasonal (Figure 2). During the summer season, net heat flux is positive throughout the Mozambique Channel. Contrary to summer, during the winter period the region is influenced by the negative heat fluxes. The amplitude of the heat fluxes from winter to summer is more than $100 \mathrm{~W} \mathrm{~m}^{-2}$, with the largest difference occurring in the 
southern part of the Mozambique Channel.
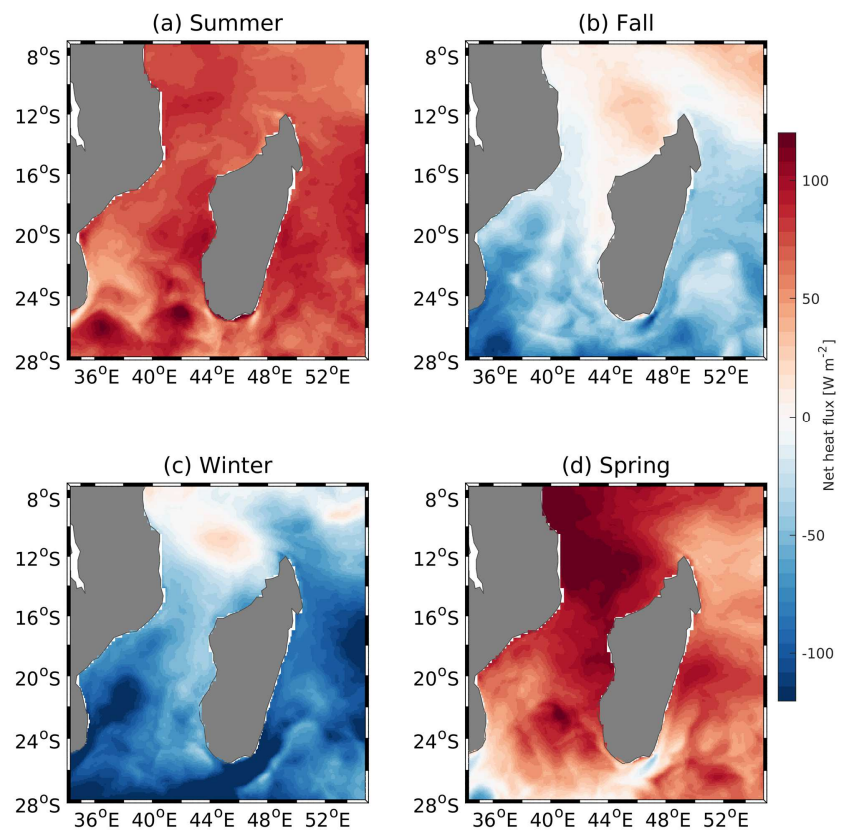

Figure 2. Variability of surface net heat flux used in the ROMS configurations for the Mozambique Channel
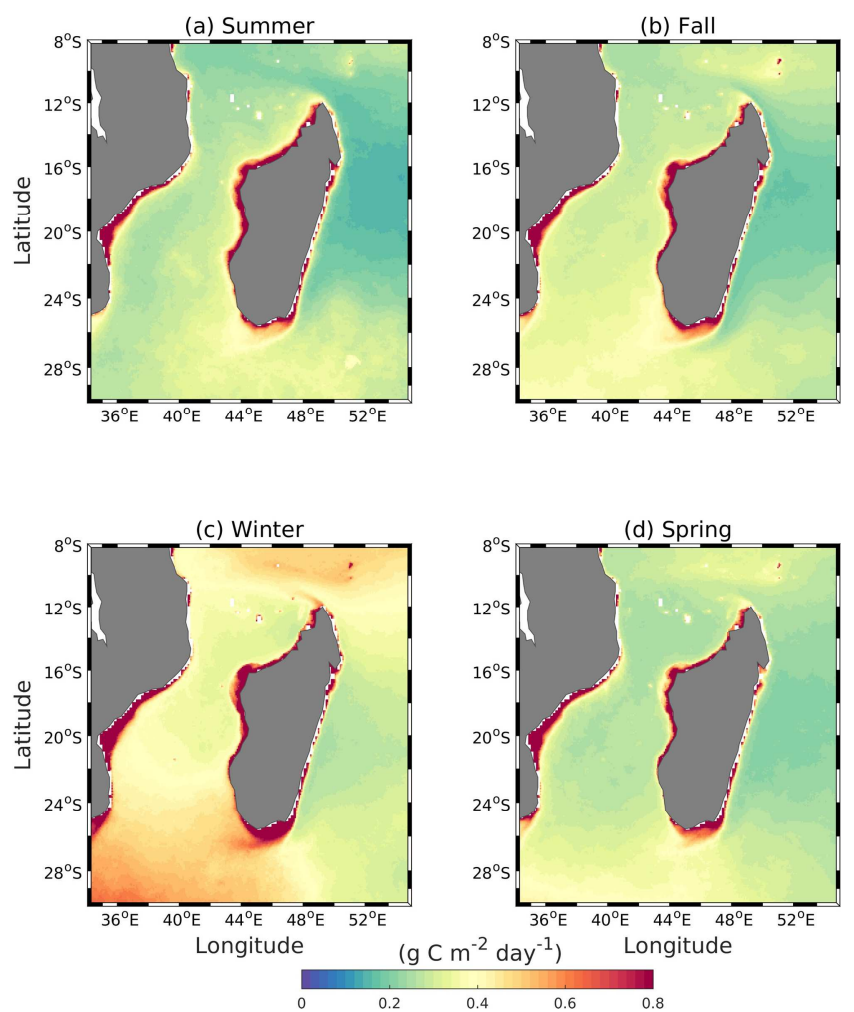

Figure 3. Depth-integrated primary production (PP) in the Mozambique Channel derived from Generalized Primary Production Model (VGPM). The $P P$ in the domain is characterized by higher production rates in winter (c) and lower in summer (a). The intermediate values are verified in fall (b) and spring (d) periods.

\subsection{Primary Production}

Depth-integrated primary production derived from VGPM in the Mozambique Channel indicates a clear seasonal cycle in the region, with higher production rates in winter, followed by intermediate rates in spring and fall and a minimum production rates in summer (Figure 3). There are slightly differences in primary production values between the northern part and rest of the channel, where the central and southern parts are the most productive areas than north, with almost double of the concentrations. These differences may be associated with intense mesoscale activity in the central region. As mesoscale eddies propagate from north to south, they interact with the coast exchanging nutrients that are than advected offshore and utilized to enhance the biological production [15].

ROMS-PISCES captures much of the spatial distribution of depth-integrated primary production in the entire domain (Figure 4) showing good agreement with the depth-integrated primary production derived from VGPM. However, there are slightly differences between ROMS-PISCES and VGPM, particularly near coastal areas where the biogeochemical model underestimates primary production. These differences in the magnitude of primary production near coastal areas are partially attributed to the absence of nutrients from river discharge, which are not included in the model configurations. The Sofala Bank $\left(18-20^{\circ} \mathrm{S}\right)$ is an example of a productive area where biological activity depends strongly on the Zambezi river flow [21].

The model also underestimates the primary production during summer, which can be attributed to the wind field used to force the model. The realistic temporal variability of wind stress that is fundamental for mixing oceanic properties such as nutrients is not included in the climatology forcing used in the model.
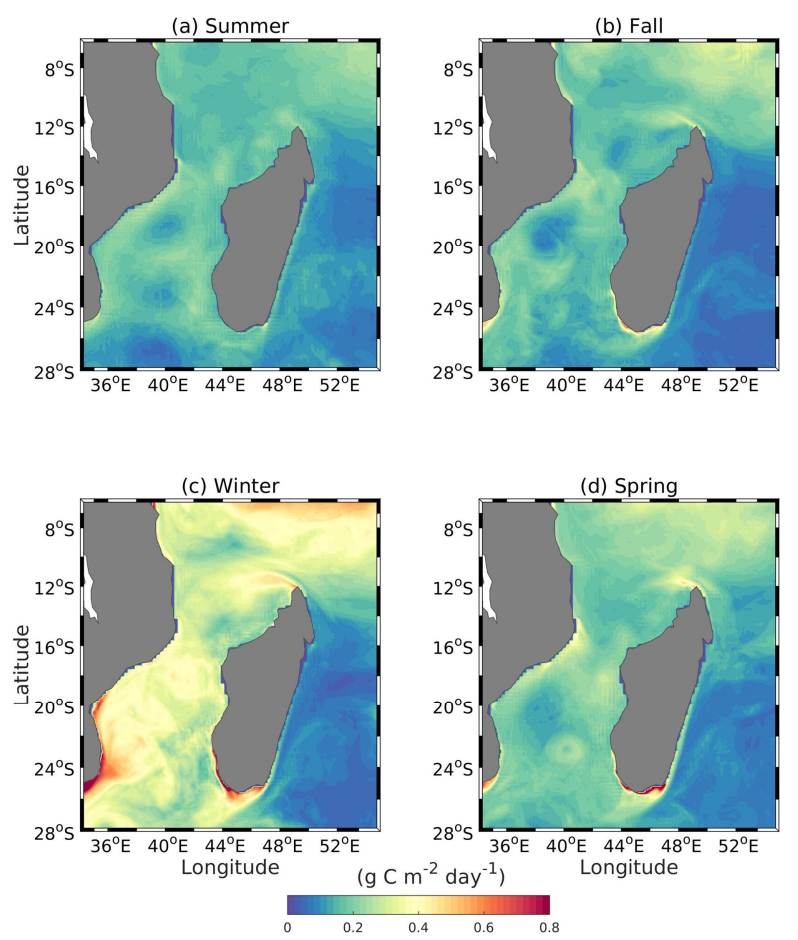

Figure 4. Maps showing the spatial distribution of primary production in the Mozambique Channel obtained from ROMS-PISCES, in summer (a); fall (b); winter (c); and spring (d).

New production integrated over the euphotic layers in the 
Mozambique Channel (Figure 5) also displays the similar seasonal variations of primary production and the estimations from VGPM. New nitrate-based primary production accounts for about half of the primary production in the vast area of the Mozambique Channel. The close relationship between new production and primary production in the region highlights the importance of new upwelled nitrate availability on the seasonal variability of biological production in the region. A brief analysis of time-depth nitrate concentrations variability is performed in the tree different regions of the Mozambique Channel.
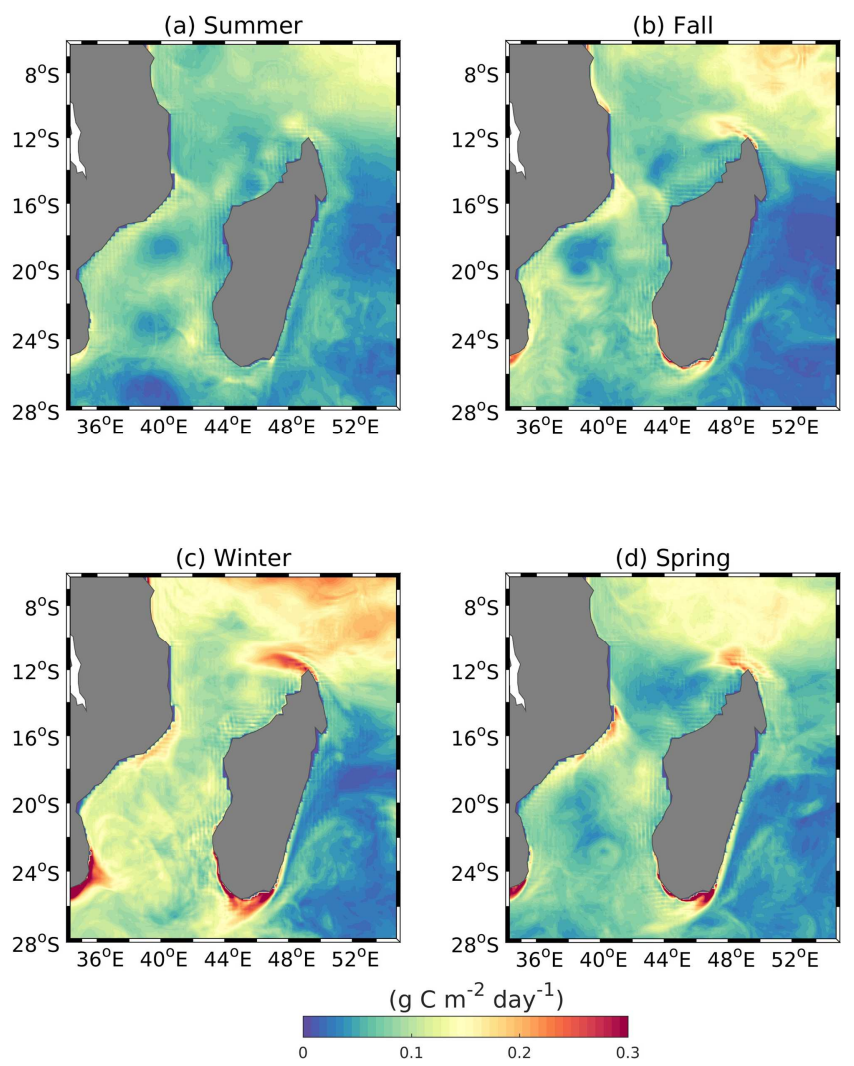

Figure 5. Same as figure 4, but for new production.

Time-depth evolution of the nitrate variability is evaluated by averaging its concentrations in the northern $\left(12-14^{\circ} \mathrm{S}\right.$, and $\left.42-44^{\circ} \mathrm{E}\right)$, central $\left(18-20^{\circ} \mathrm{S}\right.$ and $\left.40-42^{\circ} \mathrm{E}\right)$ and southern $\left(22-24^{\circ} \mathrm{S}\right.$ and $\left.40-42^{\circ} \mathrm{E}\right)$ parts of the Mozambique Channel. High values of nitrate concentrations in winter are verified in the three regions indicating that the system at large extent shifts from ammonium based primary production during the other seasons to nitrate based primary production in winter (Figure 6, color).

However, the physical mechanism that drive the seasonal variations of nitrate concentrations differ in the central part of the Mozambique Channel, when compared to north and south. The model revealed a clear seasonal signal for mixed layer depth in the northern and southern parts of the Mozambique Channel that is deeper in winter, while variability in the central sector appears to be affected by mesoscale eddies (Figure 6, dashed).

\subsection{Driving Mechanism of the Spatial Variability of Primary Production}

The mechanisms that control the spatial distribution of primary production in the Mozambique Channel are analyzed using model results from two additional sensitivity experiments with the reduction of wind stress (NOWIND) and heat fluxes (NOHEAT) fields to $1 \%$ of the original values. Values of PP from the two sensitivity experiments are contrasted to the equivalent climatological simulation of wind stress and net heat flux (CTL), where both surface forcing were kept unchanged. Higher values of the relative difference between CTL and NOWIND indicate that the wind stress is a dominant driving mechanism of depth-integrated PP in north, while its influence decreases with latitude toward central and southern parts of the channel (Figure 7-c). The apparent small contribution of wind stress in south and center should be attributed to weaker winds variability used in the model configuration (Figure 1). There is a slightly increase in PP during winter in the southern tip of Madagascar due to wind stress, in agreement with previous analysis in the region [22].
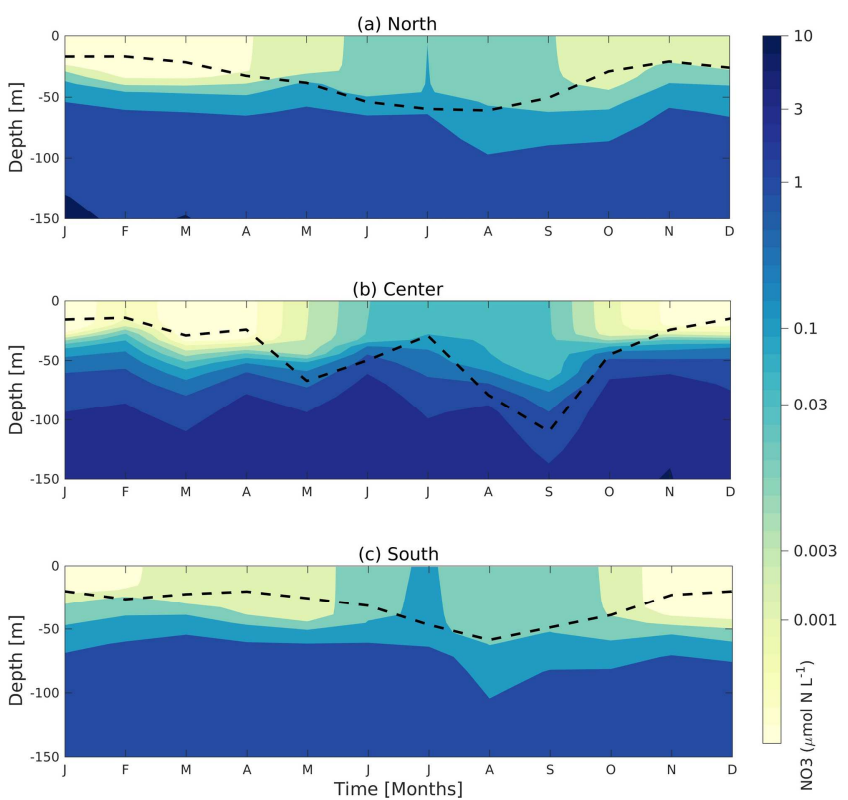

Figure 6. Time-depth evolution of nitrate (colored) overlaid by Mixed Layer Depth ( $m$ ) representing the (a) northern, (b) central, (c) southern parts of the Mozambique Channel.

In summer, the effects of winds on PP is weaker (Figure 7-a) suggesting that much of the production rate is confined to subsurface waters, where phytoplankton biomass is high due to abundance of light from above and nutrients from below the base of nutricline. In fall, when the winds start strengthening as well as in spring when winds decay, the influence of surface wind stress on the distribution of primary production is seen mainly in the central part of the Mozambique Channel (Figure 7-b \& d). Physical processes such as entrainment in fall and detrainment in spring might slightly enhance the primary production at lower rate. But, detrainment is less productive since it is not accompanied by nitrate uplift to surface layer [23]. 

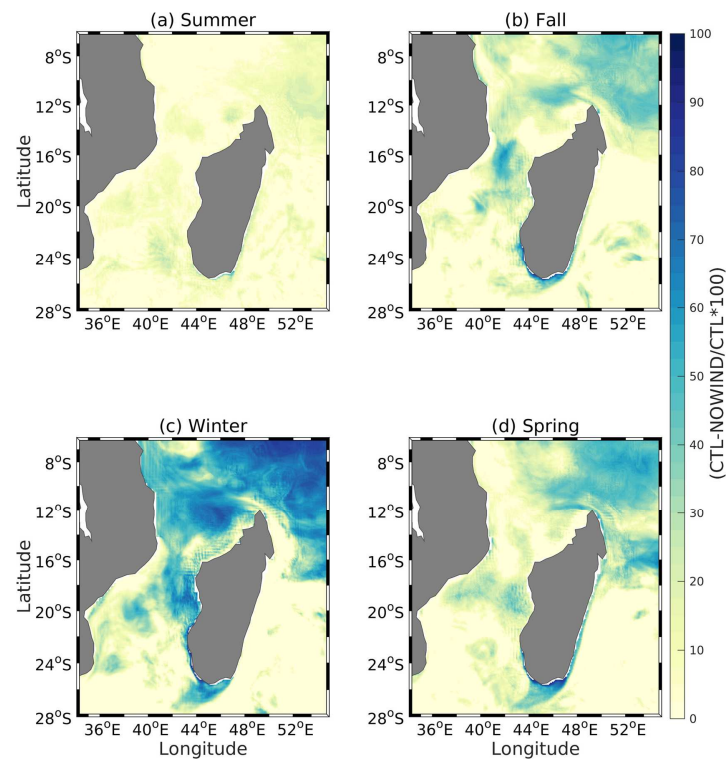

Figure 7. Relative difference (\%) between CTL and NOWIND experiment (CTL- NOWIND/CTL*100), displaying the spatial and seasonal distribution of the wind contribution to integrated PP over the euphotic layer depth in the Mozambique Channel.

Unlike the wind that dominates the northern region, net heat flux has a major influence in the central and southern parts of the Mozambique Channel during winter (Figure 8-c), following the intense heat loss, which increases with latitude at the same period (Figure 2). However, the relatively high production might also be enhanced by mesoscale eddies which are frequent in the central part of the Mozambique Channel. The relationship between mesoscale eddies and the spatial and temporal distribution of phytoplankton in the area is assessed in the next subsection.
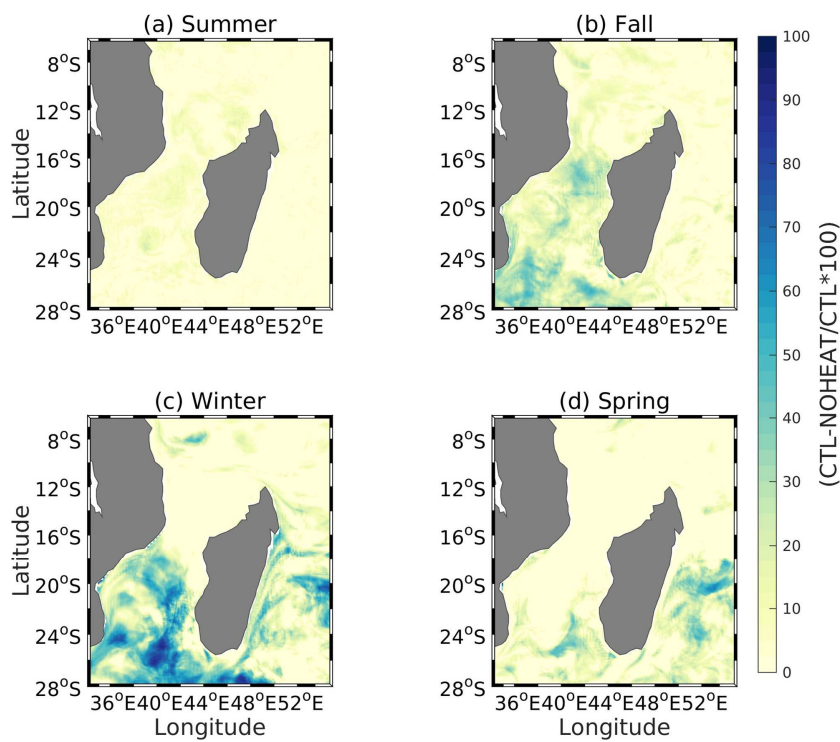

Figure 8. Same as figure 7, but for the net heat flux experiment (NOHEAT)

The effect of heat fluxes on the primary production during summer and spring is negligible (Figure 8-a \& d), which is the period when the water column is highly stratified. At this time, a loss of surface heat fluxes might be associated with the wind stress field, where relatively strong magnitudes could result in low values of sea surface temperature. As in the NOWIND experiment, NOHEAT indicate that heat fluxes have a considerable contribution for phytoplankton growth in fall, which is because of entrainment of nutrients during the onset of the deepening of the mixed layer depth.

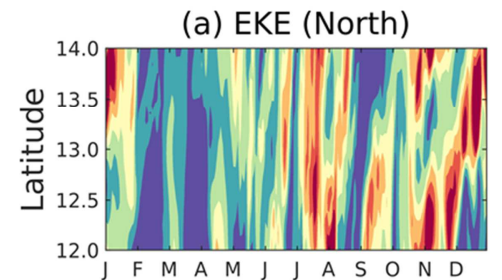

(d) $\mathrm{NO}_{3}$

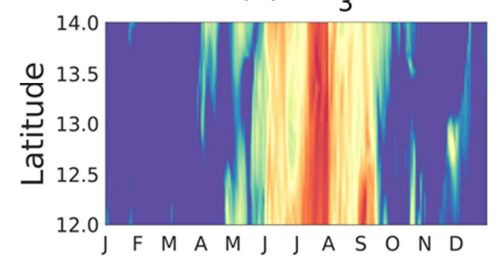

(g) Phyto

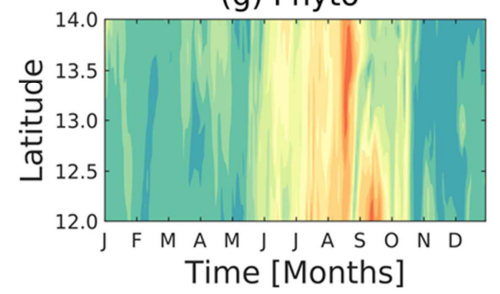

(b) EKE (Center)

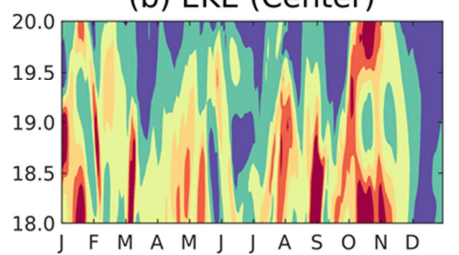

(e) $\mathrm{NO}_{3}$

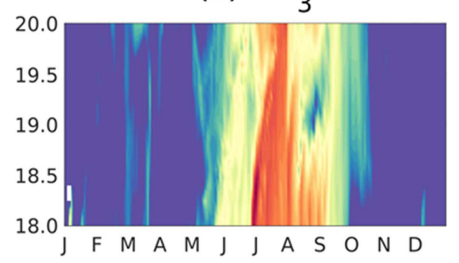

(h) Phyto

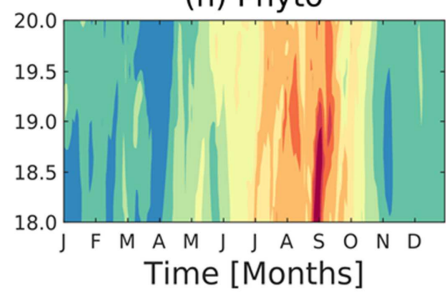

(c) EKE (South)

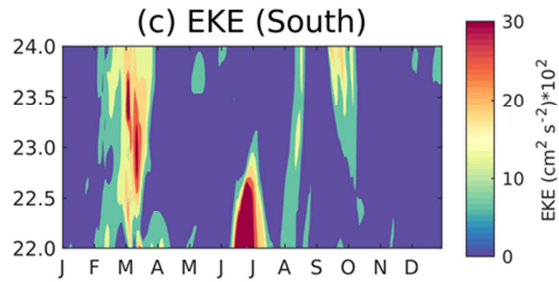

(f) $\mathrm{NO}_{3}$

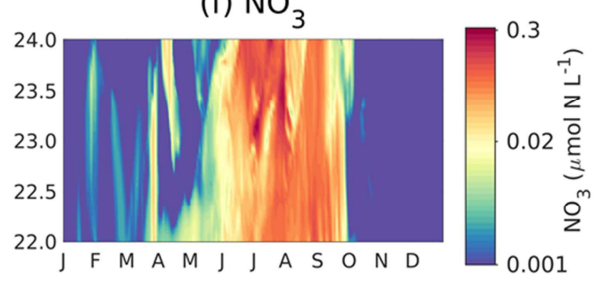

(i) Phyto

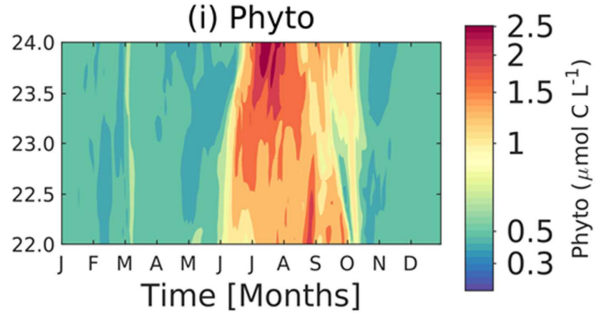

Figure 9. 2-Days snapshot displaying the relationship between EKE at the surface and the concentrations of nitrate and phytoplankton biomass in the three regions of the Mozambique Channel. 


\subsection{Effects of Mesoscale Eddies on the Temporal Variation of Phytoplankton}

The contribution of mesoscale eddies for phytoplankton variability is assessed at fixed locations mentioned in Figure 6 for the northern, central and southern parts of the Mozambique Channel, except that for the analysis in this subsection the data is averaged only over the longitude. A time evolution of surface phytoplankton and nitrate concentrations is related with eddy kinetic energy (EKE) for the three regions of the Mozambique Channel. The analysis is important to understand the role of mesoscale eddies on the seasonal variability of phytoplankton biomass in the Mozambique Channel.

The analysis revels that there is a close relationship between high EKE values and enhanced phytoplankton biomass in the Mozambique Channel, with focus in the north (Figure 9 - a, d $\& \mathrm{~g}$ ) and central (Figure 9-b, e \& h) parts, but slightly relation in the south (Figure $9-\mathrm{c}, \mathrm{f} \& \mathrm{i}$ ). The processes in which mesoscale eddies are responsible for anomalous phytoplankton growth include nitrate injection into the euphotic layer depth through vertical advection of nutrient-rich water from bellow the nutricline [24] and horizontal advection of nutrient-rich waters from coastal areas to open ocean [25]. The enhanced phytoplankton concentration due to the presence of mesoscale eddy in the region is clearly evident in the winter period. During summer, mesoscale eddies increased fairly the phytoplankton concentrations. Indicating that the occurrence of mesoscale eddies causes anomalous intensification of phytoplankton concentrations with no influence on the seasonality of primary production in the Mozambique Channel. The result emphasizes the importance of net heat flux in regulating the peak of primary production in the region.

\section{Conclusions}

In the present study, two sensitivity experiments, NOWIND (an experiment with reduced wind stress) and NOHEAT (an experiment with reduced net heat flux) are contrasted with the climatological experiment, CONTROL (all surface forcing are included in the model) in order to evaluate the contribution of wind stress and net heat flux on the spatial and temporal variability of depth-integrated primary production in the Mozambique Channel, an area characterized by intense mesoscale eddies activity.

Overall, the total primary production integrated over the euphotic layer depth in the Mozambique Channel revealed similar seasonal variability as the new primary production, with a higher production rate in winter, followed by intermediate rate in spring and fall and a minimum production rate during summer. The primary production is about twice the new production during winter in the Mozambique Channel. This indicates that the seasonality of primary production in surface depends on new upwelled nitrate from bellow the euphotic zone during winter ( $f$ -ratio of about 0.5 ) and the other periods the primary production is based on regenerated nitrate (ammonium).
Wind stress is the dominant mechanism driving the elevated nutrients that sustain primary production in north during winter than in central and southern parts of the Mozambique Channel, while net heat flux had a major influence in the southern part. The study also highlights that mesoscale eddies enhanced the primary production in the region especially during the winter period, but not for the seasonal signal. Contrary to the wintertime, mesoscale eddies increased slightly the phytoplankton concentrations during summer.

The finding of the present study highlights the need of incorporating an appropriate representation of surface dynamics in the regional oceanic models in order to better understand the biogeochemical processes in the ocean. The next step is to test the combination of high temporal surface forcing of winds and heat fluxes in the ROMS-PISCES configuration for the Mozambique Channel for better representation of the physical and biogeochemical properties in the region.

\section{Acknowledgements}

This work was supported by Coordenação de Aperfeiçoamento de Pessoal de Nível Superior - Programa de Pós-graduação Ciência para o Desenvolvimento (CAPES-PGCD) scholarship, which is a cooperation between Ministério da Educação, Brazil and Instituto Gulbenkian de Ciência, Portugal.

This work was previously presented in the WIOMSA (Western Indian Ocean Marine Sciences Association) Symposium, Mauritius, 2019.

\section{References}

[1] Ullgren, J., van Aken, H., Ridderinkhof, H., de Ruijter, W., 2012. The hydrography of the Mozambique Channel from six years of continuous temperature, salinity, and velocity observations. Deep Sea Research Part I: Oceanographic Research Papers 69, 36-50. https://doi.org/10.1016/j.dsr.2012.07.003.

[2] Saetre, R., Da Silva, A. J., 1982. Water masses and circulation of the Mozambique Channel. Revista de Investigação Pesqueira 3, 1-83.

[3] Sætre, R., Da Silva, A. J., 1984. The circulation of the Mozambique Channel. Deep Sea Research Part A. Oceanographic Research Papers 31 (5), 485-508. https://doi.org/10.1016/0198-0149(84)90098-0.

[4] Wyrtki, K., 1973. Physical oceanography of the Indian Ocean. In: The biology of the Indian Ocean. Springer, pp. 18-36.

[5] Lutjeharms, J., De Ruijter, W., Ridderinkhof, H., Van Aken, H., Veth, C., Van Leeuwen, P., Drijfhout, S., Jansen, J., Brummer, G., 2000. MARE and ACSEX: new research programmes on the Agulhas Current System. South African Journal of Science $96(3), 105-110$.

[6] De Ruijter, W. P., Ridderinkhof, H., Lutjeharms, J. R., Schouten, M. W., Veth, C., 2002. Observations of the flow in the Mozambique Channel. Geophysical Research Letters 29 (10), 140-143. https://doi.org/10.1029/2001GL013714. 
[7] Schouten, M. W., de Ruijter, W. P., Van Leeuwen, P. J., Ridderinkhof, H., 2003. Eddies and variability in the Mozambique Channel. Deep Sea Research Part II: Topical Studies in Oceanography 50 (12), 1987-2003. https://doi.org/10.1016/S0967-0645(03)00042-0.

[8] Quartly, G., Srokosz, M., 2004. Eddies in the southern Mozambique Channel. Deep Sea Research Part II: Topical Studies in Oceanography 51 (1), 69-83. https://doi.org/10.1016/j.dsr2.2003.03.001.

[9] McGillicuddy Jr, D., Robinson, A., 1997. Eddy-induced nutrient supply and new production in the Sargasso Sea. Deep Sea Research Part I: Oceanographic Research Papers 44 (8), 1427-1450. https://doi.org/10.1016/S0967-0637(97)00024-1.

[10] Franks, P. J., Wroblewski, J., Flierl, G. R., 1986. Prediction of phytoplankton growth in response to the frictional decay of a warm-core ring. Journal of Geophysical Research: Oceans 91 (C6), 7603-7610. https://doi.org/10.1029/JC091iC06p07603.

[11] Longhurst, A., 2001. A major seasonal phytoplankton bloom in the Madagascar basin. Deep Sea Research Part I: Oceanographic Research Papers 48 (11), 2413-2422. https://doi.org/10.1016/S0967-0637(01)00024-3.

[12] Ryther, J. H., Hall, J. R., Pease, A. K., Bakun, A., Jones, M. M., 1966. Primary organic production in relation to the chemistry and hydrography of the western Indian Ocean. Limnology and Oceanography $11 \quad$ (3), 371-380. https://doi.org/10.4319/lo.1966.11.3.0371.

[13] Tew-Kai, E., Marsac, F., 2009. Patterns of variability of sea surface chlorophyll in the Mozambique Channel: a quantitative approach. Journal of Marine Systems 77 (1), 77-88. https://doi.org/10.1016/j.jmarsys.2008.11.007.

[14] Machu, E., Lutjeharms, J., Webb, A., Van Aken, H., 2002. First hydrographic evidence of the southeast Madagascar upwelling cell. Geophysical research letters $29 \quad$ (21). https://doi.org/10.1029/2002GL015381.

[15] Jose, Y. S., Aumont, O., Machu, E., Penven, P., Moloney, C., Maury, O., 2014. Influence of mesoscale eddies on biological production in the Mozambique Channel: Several contrasted examples from a coupled ocean- biogeochemistry model. Deep Sea Research Part II: Topical Studies in Oceanography 100, 79-93. https://doi.org/10.1016/j.dsr2.2013.10.018.

[16] Langa, A. A., Calil, P. H., 2020. On the role of physical processes on the surface chlorophyll variability in the northern Mozambique Channel. Ocean Dynamics 70 (1), 95-114. https://doi.org/10.1007/s10236-019-01311-0.

[17] Shchepetkin, A. F., McWilliams, J. C., 2005. The regional oceanic modeling system (ROMS): a split-explicit, free-surface, topography-following- coordinate oceanic model. Ocean Modeling $\quad 9 \quad$ (4), 347-404. https://doi.org/10.1016/j.ocemod.2004.08.002.

[18] Aumont, O., Maier-Reimer, E., Blain, S., Monfray, P., 2003. An ecosystem model of the global ocean including fe, si, p collimations. Global Biogeochemical Cycles 17 (2), 1060. https://doi.org/10.1029/2001GB001745.

[19] Aumont, O., Bopp, L., 2006. Globalizing results from ocean in situ iron fertilization studies. Global Biogeochemical Cycles 20 (2), 2017. https://doi:10.1029/2005GB002591.

[20] Behrenfeld, M. J., Falkowski, P. G., 1997. Photosynthetic rates derived from satellite-based chlorophyll concentration. Limnology and oceanography 42 (1), 1-20. https://doi.org/10.4319/1o.1997.42.1.0001.

[21] da Silva, A. J., 1986. River runoff and shrimp abundance in a tropical coastal ecosystem, the example of the Sofala Bank (Central Mozambique). In: The role of freshwater outflow in coastal marine ecosystems. Springer, pp. 329-344.

[22] Ramanantsoa, J. D., Krug, M., Penven, P., Rouault, M., Gula, J., 2018. Coastal upwelling south of Madagascar: Temporal and spatial variability. Journal of Marine Systems 178, 29-37. https://doi.org/10.1016/j.jmarsys.2017.10.005.

[23] McCreary, J., Murtugudde, R., Vialard, J., Vinayachandran, P., Wiggert, J. D., Hood, R. R., Shankar, D., Shetye, S., 2009. Biophysical processes in the Indian Ocean. Indian Ocean Biogeochemical Processes and Ecological Variability, 9-32.

[24] McGillicuddy, D. J., Robinson, A. R., Siegel, D. A., Jannasch, H. W., Johnson, R., Dickey, T. D., \& Knap, A. H. (1998). Influence of mesoscale eddies on new production in the Sargasso Sea. Nature, 394 (6690), 263-266. https://doi.org/10.1038/28367.

[25] Jose, Y. S., Penven, P., Aumont, O., Machu, E., Moloney, C. L., Shillington, F., \& Maury, O. (2016). Suppressing and enhancing effects of mesoscale dynamics on biological production in the Mozambique Channel. Journal of Marine Systems, 158, 129-139. https://doi.org/10.1016/j.jmarsys.2016.02.003. 